\title{
Penggunaan Metode Genogram untuk Meningkatkan Kemampuan Perencanaan Karir
}

\author{
Nurhani Fathonah \\ SMA Negeri 1 Kertasari, Bandung \\ nurhanifathonah@gmail.com
}

\begin{abstract}
Abstrak
Pada usia remaja, mulai berpikir dan berharap mengenai perkembangan karir di masa yang akan datang, baik karir secara akademik maupun karir dalam hal pekerjaan yang baik dan mampu membanggakan. Pemikiran remaja mengenai masa depan, menjadi salah satu fokus layanan bimbingan dan konseling karir di Sekolah. Layanan bimbingan dan konseling karir di Sekolah salah satunya bertujuan untuk membantu peserta didik memahami, merencanakan serta mengambil keputusan akan kelanjutan karir dalam jangka pendek dan panjang. Untuk menunjang pelaksanaan layanan bimbingan dan konseling karir yang baik, guru bimbingan dan konseling perlu memiliki berbagai layanan dengan berbagai pendekatan, strategi dan teknik yang tepat guna. Strategi bimbingan karir melalui bimbingan klasikal dirasa mampu mengembangkan kemampuan membuat perencanaan karir pada peserta didik kelas XII SMAN 1 Kertasari tahun ajaran 2019-2020. Metode dan teknik yang digunakan yaitu bimbingan karir melalui teknik genogram. Secara konseptual, genogram berarti suatu model grafis yang menggambarkan asal-usul keluarga konseli dalam tiga generasi, yakni generasi dirinya, orang tuanya dan kakek neneknya. Genogram berfungsi untuk menyatakan karakter dari pribadi-pribadi yang terkait atau berarti bagi diri pribadi sendiri. Genogram karir menggunakan silsilah keluarga atau pohon keluarga untuk menawarkan edukasi antara anak dan keluarga, serta memberikan kesempatan bagi anak untuk belajar bagaimana mengukur dan menganalisis karir keluarga yang dapat berdampak terhadap pilihan dan keputusan keputusan karir bagi dirinya.
\end{abstract}

Kata Kunci: Genogram; Perencanaan Karir; Remaja.

\section{PENDAHULUAN}

SMA (Sekolah Menengah Atas) merupakan salah satu lembaga pendidikan formal tingkat menengah. Setelah lulus SMA, diharapkan peserta didik mampu melanjutkan ke pendidikan yang lebih tinggi (kuliah) atau memasuki dunia kerja dengan bekal keterampilan yang dimilikinya. Bimbingan dan konseling sebagai bagian yang terintegrasi dalam satuan pendidikan, sudah semestinya mengambil peran dalam pencapaian tujuan 
pendidikan. Guru BK/konselor berperan untuk memfasilitasi peserta didik agar mampu mengembangkan potensi dirinya atau mencapai tugas-tugas perkembangannya (Yusuf, 2005:11).

Berdasarkan usia, peserta didik SMA termasuk remaja yang berkisar antara usia 13-18 tahun (Hurlock, 1980:270). Pada usia tersebut, remaja mulai berpikir dan berharap mengenai perkembangan karir di masa yang akan datang, baik karir secara akademik maupun karir dalam hal pekerjaan yang baik dan mampu membanggakan. Hurlock (1980:221) mengemukakan, bahwa anak sekolah menengah atas mulai memikirkan masa depan mereka secara bersungguh-sungguh. Besarnya minat remaja terhadap pendidikan sangat dipengaruhi oleh minat mereka terhadap pekerjaan (Hurlock, 1980: 220). Artinya minat peserta didik SMA terhadap pendidikan akan dipengaruhi oleh minat terhadap pekerjaan.

Pemikiran remaja mengenai masa depan, menjadi salah satu fokus layanan bimbingan dan konseling karir di Sekolah. Layanan bimbingan dan konseling karir di Sekolah salah satunya bertujuan untuk membantu peserta didik memahami, merencanakan serta mengambil keputusan akan kelanjutan karir dalam jangka pendek dan panjang. Untuk menunjang pelaksanaan layanan bimbingan dan konseling karir yang baik, guru bimbingan dan konseling perlu memiliki berbagai layanan dengan berbagai pendekatan, strategi dan teknik yang tepat guna. Sehingga persentase dan ragam masalah karir yang dihadapi peserta didik dapat ditekan seminim mungkin. Hal tersebut menjadi dasar kebutuhan akan upaya pengembangan penyediaan sumber pelaksanaan layanan bimbingan dan konseling karir yang tepat dan maksimal.

Sunaryo Kartadinata et al. dalam petunjuk teknis Inventori Tugas Perkembangan (ITP)-SMA (Kartadinata, 2003:105) mengadaptasi tugas perkembangan model Loevinger dan menyusunnya menjadi ITP yang disesuaikan dengan kondisi di Indonesia. Dalam ITP terdapat sebelas aspek tugas perkembangan yang harus dimiliki serta diselesaikan oleh siswa SMA, yaitu : (1) Landasan Hidup Religius, (2) Landasan Perilaku Etis, (3) Kematangan Emosi, (4) Kematangan Intelektual, (5) Kesadaran Tanggung Jawab, (6) Kesadaran Gender, (7) Pengembangan Pribadi, (8) Perilaku Kewirausahaan (Kemandirian Perilaku Ekonomis), (9) Wawasan dan Kesiapan Karir, (10) Kematangan Hubungan dengan Teman Sebaya, (11) Kesiapan Diri untuk Menikah dan Berkeluarga. Aspek wawasan dan persiapan karir meliputi empat sub aspek yaitu pemahaman jenis pekerjaan, kesungguhan belajar, upaya meningkatkan keahlian dan perencaan karir. Sub aspek dalam tugas perkembangan wawasan dan persiapan karir, salah satu butirnya adalah perencanaan karir dan menjadi salah satu tugas perkembangan karir yang harus dipenuhi oleh siswa SMA sesuai dengan fase perkembangannya.

Hasil penyebaran ITP di SMAN 1 Kertasari yang dilakukan pada awal tahun pelajaran 2019-2020 dalam rangka needs assessment dalam penyusunan program BK, didapatkan data tingkat pencapaian tugas perkembangan siswa kelas XII pada aspek wawasan dan kesiapan karir baru mencapai pada tingkat seksama, sedangkan berdasarkan 
rentang pencapaian tugas perkembangan siswa SMA (konformistik - sadar diri - seksama individualistik) harus sudah mencapai tingkat individualistik. Belum terpenuhinya secara maksimal salah satu aspek dalam tugas perkembangan, yaitu aspek wawasan dan kesiapan karir mengindikasikan bahwa siswa SMA Negeri 1 Kertasari belum memiliki perencaan karir yang matang.

Selain itu, data yang diperoleh berdasarkan hasil wawancara terhadap peserta didik kelas XII SMAN 1 Kertasari tahun ajaran 2019-2020 dapat disimpulkan tiga masalah yang muncul pada peserta didik kelas XII terhadap karir yaitu: 1) tidak tahu rencana yang akan dikerjakannya setelah lulus sekolah; 2) bingung dalam memilih jurusan di Universitas; dan 3) memilih karir sesuai dengan pekerjaan orang tuanya (tetapi belum tahu bagaimana caranya). Berdasarkan uraian permasalahan yang muncul pada peserta didik kelas XII SMAN 1 Kertasari tahun ajaran 2019-2020, dapat dilakukan identifikasi faktor peyebab terjadinya masalah perkembangan karir pada peserta didik kelas XII, sebagai berikut: 1) peserta didik kelas XII merasa tidak mendapatkan informasi yang sistematis tentang berbagai jenis dunia lanjutan setelah SMA (kuliah, bekerja, kursus/pelatihan); 2) peserta didik kelas XII kurang mendapat informasi tentang persyaratan masuk universitas dan dunia kerja; dan 3) peserta didik kelas XII mempunyai sosok sukses yang berpengaruh terhadap perencanaan karirnya (orang tua atau keluarganya).

Memperhatikan identifikasi masalah perkembangan karir pada peserta didik kelas XII SMAN 1 Kertasari tahun ajaran 2019-2020, dapat dianalisis bahwa peserta didik kelas XII SMAN 1 Kertasari tahun ajaran 2019-2020 kurang mampu membuat perencanaan karir. Membuat perencanaan karir sangat berdampak pada kesuksesan seseorang, kesuksesan dalam pekerjaan dapat diraih melalui usaha yang sungguh- sungguh penuh pengorbanan dan perjuangan. Mereka belajar dan bekerja secara tekun untuk mewujudkan kesuksesan dalam pekerjaannya. Mereka merasa senang dalam belajar dan bekerja yang sesuai dengan dirinya. Mereka bahagia karena lingkungan di sekitarnya dapat menerima diri dan menerima pekerjaanya. Mereka bahagia karena mampu berprestasi di bidang pekerjaan yang dipilihnya (Supriatna, M. \& Budiman, N., 2009:6). Kecil kemungkinan seseorang dapat sukses tanpa informasi yang memadai tentang karir pada masa depan. Sehingga, permasalahan terkait dengan perkembangan karir tidak dapat diabaikan, terutama di kelas XII SMA sebagai peserta didik tahun terakhir dan akan segera memasuki dunia lanjutan setelah lulus SMA.

Strategi bimbingan karir melalui bimbingan klasikal dirasa mampu mengembangkan kemampuan membuat perencanaan karir pada peserta didik kelas XII SMAN 1 Kertasari tahun ajaran 2019-2020. Metode dan teknik yang digunakan yaitu bimbingan karir melalui teknik genogram. Secara konseptual, genogram berarti suatu model grafis yang menggambarkan asal-usul keluarga konseli dalam tiga generasi, yakni generasi dirinya, orang tuanya dan kakek neneknya. Genogram berfungsi untuk menyatakan karakter dari pribadi-pribadi yang terkait atau berarti bagi diri pribadi sendiri. 
Genogram juga merupakan suatu alat untuk menyimpan informasi yang dicatat selama wawancara antara konselor dengan konseli mengenai orang-orang dalam asal- usul keluarga konseli (Supriatna, 2009:62-63). Pemilihan karir pada masa remaja dipengaruh oleh orang lain, yang berarti adanya (significant-other influences). Dengan kata lain, ketika individu mengidentifikasi dan menentukan pemilihan karirnya dipengaruhi oleh orang lain yang sangat berarti baginya (Supriatna, 2009: 62). Uraian tersebut menunjukkan pentingnya penggunaan teknik genogram untuk meningkatkan kemampuan perencanaan karir siswa, agar siswa nantinya dapat memilih berbagai tujuan karir dalam hidupnya sesuai dengan berbagai peluang yang ada serta sesuai dengan berbagai arahan minat dan potensi dalam dirinya.

\section{PEMBAHASAN}

\section{Genogram}

Genogram secara istilah berasal dari 2 kata, yaitu gen (unsur keturunan) dan gram (gambar atau grafik). Dalam bahasa Indonesia, genogram dapat dipadankan dengan gambar silsilah keluarga. Secara konseptual genogram berarti suatu model grafis yang menggambarkan asal-usul keluarga konseli dalam tiga generasi, yakni generasi dirinya, orangtuanya dan kakek neneknya. Adapun pengertian lain mengenai genogram adalah sebuah presentasi bergambar dari hubungan-hubungan yang terdapat di dalam sebuah keluarga dari berbagai generasi. Genogram disebut sebagai silsilah keluarga dari satu generasi ke generasi lainnya di keluarga kita. Bentuk dari genogram hampir sama dengan "family tree" atau pohon keluarga, tetapi dengan penjelasan dan informasi yang lebih lengkap. Genogram juga merupakan suatu alat untuk menyimpan informasi yang dicatat selama wawancara, antara konselor dengan konseli mengenai orang-orang dalam asal-usul keluarga konseli (Supriatna, 2009:62-63). Secara sederhananya dapat dilihat dalam gambar di bawah ini.

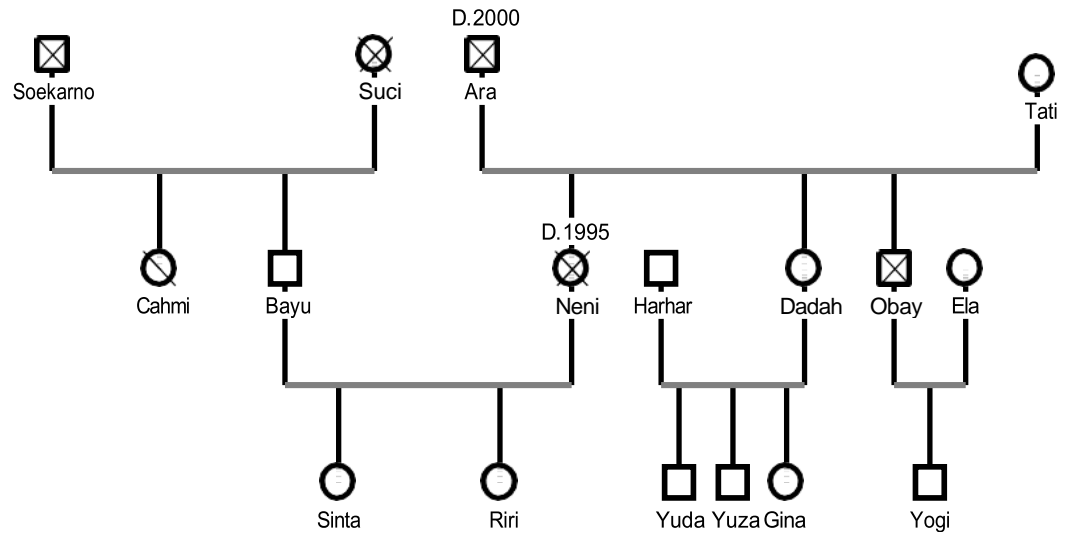

Gambar 1. Contoh Genogram 


\section{Penggunaan Simbol-Simbol dalam Genogram}

Genogram adalah sebuah presentasi bergambar dari hubungan-hubungan yang terdapat di dalam sebuah keluarga dari berbagai generasi.Genogram berisi banyak keterangan mengenai keadaan keluarga. Pertama, berisi data dasar yang ditemukan dalam pohon keluarga seperti nama, jenis kelampibar tanggal lahir dan tanggal kematian dari tiap individu. Data tambahan dapat berupa pekerjaan, pendidikan, kejadian hidup yang penting, penyakit kronis, perilaku sosial, sifat dasar dalam hubungan keluarga, hubungan emosional, dan hubungan sosial. Beberapa genogram juga meliputi informasi gangguan yang terjadi dalam keluarga misalnya alkoholosime, depresi, penyakit, persekutuan, dan keadaan hidup. Genogram dapat sangat signifikan karena tidak ada batasan tipe data yang akan dimasukkan. Adapun penggunaan simbol dalam pembuatan konstruk genogram, seperti contoh berikut.

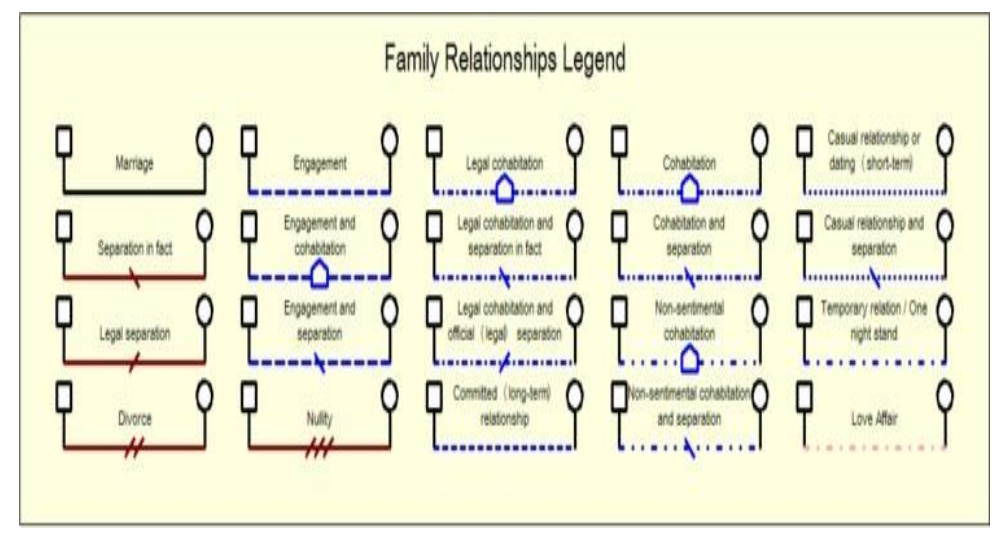

Gambar 2. Simbol Standar dalam Genogram

\section{Fungsi dan Tahapan Genogram}

Genogram berfungsi untuk menyatakan karakter dari pribadi-pribadi yang terkait atau berarti bagi diri kita sendiri. Genogram mampu memberikan berbagai informasi mengenai diri dan anggota keluarga yang lain, secara sejarah keluarga, berbagai kejadian-kejadian penting yang terjadi serta bagaimana pola hidup dan interaksi anggota keluarga yang lain mampu menginspirasi individu untuk perwujudan hidup yang lebih baik. Penggalian informasi dalam genogram didapat dengan melakukan berbagai tahapan yang ada. Secara umum tahapan genogram terdiri dari tiga tahap dan proses, yaitu:

a. Tahap 1. Konstruksi Genogram (ilustrasi yang disajikan menggambarkan secara fiktif tentang suatu silsilah keluarga dengan jumlah yang terbatas);

b. Tahap 2. Identifikasi Jabatan (dilakukannya wawancara dengan konseli untuk mengembangkan alternatif dalam upaya mengidentifikasi jabatan); dan

c. Tahap 3. Eksplorasi Konseli(tahap ini bertujuan untuk mengeksplorasi konseli 
mengenai pemahaman dirinya, lingkungan khususnya lingkungan kerja serta kemampuan dalam merencanakan dan membuat keputusan bagi karirnya sekarang dan masa yang akan datang).

\section{Perencanaan Karir}

Perencanaan karir merupakan salah satu sikap karir agar seorang individu memiliki orientasi karir yang matang. Mc. Murray (Sri Prihartono, 2007, dalam Sinta, 2010 : 52) memaparkan makna perencanaan karir sebagai sebuah proses dari kesadaran diri yang mencakup kesadaran akan kekuatan dan kelemahan diri, kesadaran akan pilihan-pilihan dan kesadaran terhadap konsekuensi-konsekuensi dari pilihan karir yang ada. Perencanaan karir juga memiliki makna sebagai sebuah pengidentifikasian tujuan-tujuan karir dan penyusunan program seseorang yang berkaitan dengan pekerjaan, pendidikan serta pengalaman-pengalaman dalam kerangka perkembangan yang akan memberikan arah, waktu dan serangkaian langkah- langkah untuk mecapai tujuan karir yang spesifik.

Perencanaan karir merupakan salah satu bagian dari aspek dari perkembangan sikap karir. Super (dalam Sharf, 1992: 156), menunjukkan bahwa orientasi karir total seseorang individu terdiri dari beberapa aspek, yaitu: (1) Perkembangan sikap-sikap karir, yang meliputi perencaaan karir dan eksplorasi karir; dan (2) Perkembangan pengetahuan dan keterampilan, yang meliputi pengetahuan tentang pembuatan keputusan dan pengetahuan tentang informasi dunia kerja.

Super (dalam Sharf, 1992: 156) memaparkan bahwa Perencaan karir adalah suatu proses dimana individu dapat mengidentifikasi dan mengambil langkah-langkah untuk mencapai tujuan-tujuan karirnya. Perencanaan karir melibatkan pengidentifikasian tujuantujuan yang berkaitan dengan karir dan penyusunan rencana-rencana untuk mencapai tujuan tersebut.

Dillard, 1985 (dalam Sofwan, 2015:47-48), mengemukakan bahwa perencanaan karir merupakan proses pencapaian tujuan karir individu, yang ditandai dengan adanya: tujuan yang jelas setelah menyelesaikan pendidikan, cita-cita yang jelas terhadap pekerjaan, dorongan untuk maju dalam bidang pendidikan dan pekerjaan yang dicitacitakan, persepsi yang realistis terhadap diri dan lingkungan, kemampuan mengelompokkan pekerjaan yang diminati, memberikan penghargaan yang positif terhadap pekerjaan dan nilai-nilai, kemandirian dalam proses pengambilan keputusan,kematangan dalam hal mengambil keputusan, dan menunjukan cara-cara realistis dalam mencapai cita-cita pekerjaan.

\section{Tujuan dan Manfaat Perencanaan karir}

Perencanaan karir merupakan salah satu aspek esensial dalam perkembangan kepribadian individu, dan yang harus menjadi kepedulian pendidikan maupun bimbingan dan konseling. Kecakapan mengambil keputusan mengenai aspek-aspek karir yang akan ditempuh, merupakan esensi perencanaan karir. Sedangkan keputusan yang diambil seseorang mengenai aspek-aspek karir yang akan ditempuh itu tidak lepas 
dari timbangannya terhadap berbagai faktor yang ada dalam tatanan kehidupan masyarakat yang merupakan sumber nilai dan tempat tersedianya berbagai hal yang dapat dimanfaatkan oleh individu bagi pengembangan dirinya.

Tujuan pentingnya perencanaan karir menurut Dillard, 1985 (dalam Sofwan, 2015:48) adalah sebagai berikut:

a. Memperoleh kesadaran dan pemahaman diri (acquiring self awarness and understanding);

b. Mencapai kepuasan pribadi (attaining personal satisfications);

c. Mempersiapkan diri untuk memperoleh penempatan dan penghasilan yang sesuai (preparing for adequate placement);

d. Efisiensi usaha dan penggunaan waktu (efficiently using time and effort).

Dillard, 1985 (dalam Sinta, 2010:53) mengungkapkan beberapa manfaat yang diperoleh siswa jika mampu merencanakan karirnya adalah sebagai berikut.

a. Pengetahuan dan pemahaman tentang diri sendiri akan lebih meningkat.

b. Mengetahui berbagai macam dunia karir.

c. Cakap untuk membuat keputusan secara efektif.

d. Memperoleh informasi yang terarah mengenai karir yang tersedia.

e. Cakap memanfaatkan kesempatan karir yang sesuai dengan kemampuannya.

\section{Langkah-Langkah Perencanaan Karir}

Adapun langkah-langkah untuk mencapai perencanaan karir (career planning), yang dikemukan oleh Dillard bahwa diperlukan sebuah penilaian tersendiri mengenai Dillard, 1985 (dalam Sinta 2010 :54).

a. Aptitudes (bakat), diperlukannya sebuah analisis pengetahuan serta pemahaman mengenai potensi alami yang dimiliki konseli, serta pengembangan keterampilan dalam menunjang perencanaan karirnya.

b. Interest (minat), minat seseorang tumbuh melalui berbagai pengelaman kegiatan yang pernah ia lakukan. Sebuah bakat akan lebih bagus jika ditunjang dengan besaran minat yang tinggi juga. Karena dengan minat/ sebuah keinginan, maka pencapaian sebuah kesuksesan akan lebih terarah dan semakin dekat dengan tujuan.

c. Personality (kepribadian), pencapaian kesuksesan karir semakin cemerlang jika ditunjang dengan kepribadian yang matang dan sesuai dengan tuntutan pekerjaan. Seperti yang dikatakan Dillard, yakni having the necessary aptitude, values and interest may help you in your career, but just as important, you must have personality traits which the career requires.

d. Values (nilai), sistem nilai yang dianut oleh setiap individu menjadi faktor penentu dalam perkembangan karirnya. Sistem nilai seseorang muncul seiring dengan berkembangnya belief orang tersebut. 
e. Career opporturnities (peluang karir), sebuah informasi karir sangat diperlukan sebagai penunjang pengembangan serta pelengkap dari sebuah perencanaan karir yang telah dibuat. Mengindentifikasi keunggulans serta kelemahan salah satu langkah dalam mencari sebuah peluang karir.

f. Performance (penampilan/pertunjukan diri), mempelajari kebutuhan dari karir yang akan kita jalani kedepan merupakan sebuah bagian dari perencanaan karir yang matang.

g. Lifestyle (gaya hidup).

Berikut digambarkan sebuah sistematik sebuah model proses perencanaan karir (Dillard, 1985 (dalam Sinta, 2010: 55).

\begin{tabular}{|c|c|c|c|c|}
\hline $\begin{array}{c}\text { Self-assessment } \\
\text { of personal skills } \\
\text { and values }\end{array}$ & $\begin{array}{l}\text { Awareness } \\
\text { of need to } \\
\text { plan }\end{array}$ & $\begin{array}{l}\text { Stated } \\
\text { career } \\
\text { goals }\end{array}$ & $\begin{array}{c}\text { Commitment and } \\
\text { application of } \\
\text { steps to achieve } \\
\text { goals }\end{array}$ & $\begin{array}{l}\text { Evaluastion } \\
\text { of outcome }\end{array}$ \\
\hline
\end{tabular}

\section{Gambar 3. Proses Perencanaan Karir}

\section{SIMPULAN}

Genogram sebagai salah satu teknik dalam pemberian layanan bimbingan karir, menjadi salah satu jalan keluar bagi pelaksanaan layanan bimbingan karir yang tepat guna dan komprehensif. Genogram karir menggunakan silsilah keluarga atau pohon keluarga untuk menawarkan edukasi antara anak dan keluarga, serta memberikan kesempatan bagi anak untuk belajar bagaimana mengukur dan menganalisis karir keluarga yang dapat berdampak terhadap pilihan dan keputusan keputusan karir bagi dirinya. Selain itu, genogram menjadi alat yang dipersiapkan untuk membantu konselor dan konseli dalam melakukan konseling karir dengan suasana yang menyenangkan, sehingga dapat mendorong keterbukaan dan semangat konseli.

\section{DAFTAR PUSTAKA}

Adiputra, Sofwan. (2015). Penggunaan Teknik Modeling Terhadap Perencanaan Karir Siswa. Jurnal Fokus Konseling Volume 1 No. 1, Januari 2015 Hlm. 45-56. (Online) diakses tanggal 16 Oktober 2019.

Caryono, Suhas dan Isnaeni Endang. (2014). Upaya Peningkatan Kemampuan Perencanaan Karir Siswa Melalui Bimbingan Kelompok Pada Siswa Kelas XII IPA di SMA N 8 Purworejo. (Online) diakses tanggal 16 Oktober 2019.

Creswell, John W. (2012). Educational Research: Planning, Conducting, and Evaluating Quantitative and Qualitative Research ( $4^{t h}$ ed). Boston: Pearson Education. 
Emzir. (2008). Metodologi Penelitian Pendidikan: Kuantitatif dan Kualitatif. Jakarta: PT. Raja Grafindo Persada.

Hurlock, E. (1980). Psikolgi Perkembangan (Suatu Pendekatan Sepanjang Rentang Kehidupan). Jakarta: Erlangga.

Malott, K.M. (2005). Using Genograms to Facilitate Undergraduate Students' Career Development. Career Development Quarterly, 53, hlm. 178-186.

Okiishi, R. (1987). The Genogram As A Tool In Career Counseling.Journal of Counseling and Development, 66, 139-143.

Rahayu, Sinta. (2010). Pengaruh Layanan Genogram Terhadap Kemampuan Perencanaan Karier Siswa. Bandung: Skripsi.

Rahmi, R. S. (2009). Program Bimbingan untuk Meningkatkan Kemampuan Merencanakan Karier Siswa Sekolah Menengah Atas. Bandung: Skripsi.

Sharf, Richard. (1992). Applying Careeer Development Theory to Counseling. California: Brooks/Cole Publishing Company.

Sukmadinata, N S. (2008). Metode Penelitian. Bandung : Remaja Rosdakarya.

Supriatna, Mamat. (2008). Analisis Genogram Sebagai Alat Konseling Karir. Jurnal Pendidikan Psikologi dan Bimbingan. (Online) diakses tanggal 16 Oktober 2019.

Supriatna, Mamat dan Budiman, Nandang. (2009). Bimbingan Karir di SMA. Bandung: eBook.

Yusuf, A. M. (2005). Kiat Sukes dalam Karier. Bogor : Penerbit Ghalia Indonesia. 
288 | Fathonah - Penggunaan Metode Genogram ... 